\title{
How To Raise Social Capital: Experiential Exercise Teaching Note
}

Peter H. Hackbert, (Email: phackbert@sierranevada.edu), Sierra Nevada College

\section{INTRODUCTION}

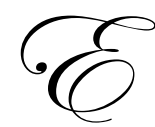

ntrepreneurship is alive and thriving in our nation's colleges and universities. The distinctive entrepreneurial spirit and signature entrepreneurial pedagogies have spread from the business school to the entire campus. To support this growth a wide variety of entrepreneurial competencies are emerging in the entrepreneurship education literature.

This experiential exercise is intended to illustrate the significance of social capital or networking. The exercise is based on more-in-depth, sociometric survey instruments developed by sociologist Ron S. Burt. Researchers have used Burt's instrument to conduct network research in organizations.

This version is intended for undergraduate liberal art college students as well as graduate students - not just MBA students but student activists, scientists, engineers, medical doctors and others. It is intended for those with an aspiration for success. It is intended for the solo sustainer, the visionary entrepreneur, the expert idea generator, personal achiever, and corporate entrepreneur. Because several of the questions are framed around the college years, the version tends to be biased towards that academic context, early stage opportunity recognition stages and towards entrepreneurial job search contacts.

The instrument tends to be biased toward strong ties because a limited number of names are elicited. Students are more likely to recall contacts with whom they have fairly regular or close interactions, than their more distant acquaintances who also provide important network resources.

\section{COMPUTING THE DATA}

The instructor will need to process and analyze the data collected from students. In this version, there are 13 variables (Entrepreneurial Network Information, 1 to 3 and $4 \mathrm{a}$ to $4 \mathrm{k}$ ). For each variable the instructor computes the mean, standard deviation, and range. As well, instructors can use the individual information provided on page six to calculate the means, and standard deviations of last job before college, current job, or by other groups or interest, for example gender, race/ethnicity, or nationality. Finally, the instructor can compute T-tests to illuminate significant differences between relevant groups. The author's experience in several different settings is that few group differences are significant. The most interesting finding from this analysis is that the students' responses often span the entire range measured by each of the indicators.

An alternative is to have students simply come with the last page of their exercise filled out. In class, during the course of the lecture described below, the instructor might then ask students to share and post the characteristics of their network. Since the range of responses tends to be so extensive, it is useful to get students with very different networks to contribute to the conversation.

\section{CLASS DISCUSSION}

In teaching the Entrepreneurial Network Experiential Exercise, the instructor might open the class by asking students to share their reactions to filling out the experiential exercise. See TN-Exhibit 1 for an outline of my complete teaching and learning plan. The instructor can elicit students' view of what constitutes a good professional network. The instructor might ask the class, "What is an effective network? What does it provide?" As the class begins to generate a list, the instructor can write their responses on the board. The instructor may organize the board 
notes by separating characteristics of students' networks (e.g., types of relationships) from their outcomes or results (e.g., access to information or job opportunities).

Once the list is developed, the instructor can conduct an interactive lecture and conversation on the dimensions of effective networks. The instructor might ask students to analyze the strengths and weaknesses of their own network choices: What do their current networks provide? What do they lack? What strategies for network building would help them to eliminate these gaps? As they consider these questions, the instructor could share relevant research findings and help them to define for themselves the dimensions of effective networks.

Following this lecture the instructor might break students into small groups so that they may discuss the implications for building their networks and in future professional settings. The instructor might ask students to think critically about their various approaches to networking. The instructor might debrief their conversations, and conclude the class leaving students with some guidelines for developing effective networks (See TN - Exhibits 2, 3 and 4).

\section{NETWORK DEFINITION}

An entrepreneurial network is the set of relationships critical to one's ability to marshal uncontrollable resources, to get things done, to get ahead, and develop personally and professionally. Social capital - the resource available from one's networking of relationships - is critical to the development of new venture opportunities. There are many types of networks. The instructor could advocate that students should differentiate between them as they conduct their analysis. In particular, the instructor might suggest that they distinguish between their task-oriented contacts, their career-development relationships, and their social ties or friendships. Students will differ in whether they maintain social contacts that serve all three purposes, or preserve independent social circles. This difference in approach can provide interesting topics.

\section{DIMENSIONS OF EFFECTIVE NETWORKS}

\section{Incorporate A Variety Of Contacts}

Effective networks incorporate different kinds of people, including a balance of contacts who are inside and outside one's entrepreneurial team, organization, function, demographic, and peer group. It is a fact that "likes attract." The students' data shows clearly that we prefer to include people in our networks whose salient social characteristics are similar to our own. While this may provide valuable support, the instructor might instruct them to explore the danger of homogeneity in networks by emphasizing the importance of range - maintaining a broad base of contacts (See page 4-5, Entrepreneurial Network Information, questions 1 and 4).

Diversity is a key quality of a strong network. Research shows that people often have a reasonable diversity in their networks, but, as this exercise often reveals, people typically neglect key sectors of their own networks. For example, one student may have contacts in a diverse range of organizations, but few ties to senior colleagues, while another may find that she ignores ties outside her function. Raising students' awareness about these gaps is the purpose of this lecture. The instructor might ask students to consider whether the kind of people in their network reflects the complexity of their current college situation, work situation, dependencies, and future opportunities. The instructor could also explore how social characteristics, like gender, race, and nationality, shape networks.

\section{Encompass Different Types Of Relationships}

Effective networks also encompass different types of relationship form short-term instrumental ties to longstanding collegial relationship. The instructor might ask students to consider their preferred approaches to networking: Do they favor those contacts who will be most instrumental or those with whom they can have the most rewarding relationships? Students assess this dimension when they report the number of "very close" relationship they listed on their Entrepreneurial Network Grid (see page 7, Entrepreneurial Network Information, question 2). 
Some students favor high-trust relationships, or "strong" ties. These bonds and reciprocal relationships ensure reliability under conditions of uncertainty. Other students prefer to focus on their short-term needs when building their networks of relationships, establishing mostly "weak" ties. This transaction-based relationship can provide useful connections for accomplishing specific tasks. However those students whose network consists solely of weak ties may preclude building a strong base of support for their personal and professional development. Conversely, those who favor "strong" ties may be forfeiting important learning opportunities by excluding potentially useful network members. In focusing on the different uses for "strong" and "weak" ties, the instructor could encourage students to reflect on their network building preferences.

\section{Provide Links To Multiple Networks}

Finally, effective networks provide links to multiple networks, serving as ports of entry to social and organizational groups to which one does not have direct access. To be "well-connected" in this regard is to position oneself on the boundary of many non-intersecting networks. Students access this dimension when they report the density of their network (See page 6, Entrepreneurial Network Information, question 2).

Density refers to the extent to which people within one's network know each other. My students have density scores ranging from as low as $5 \%$ to as high as $100 \%$. This latter score indicates that all of their actual contacts know each other. The instructor might caution the students that such a high level of density may signal a "redundant" or "inbred" network that will not afford them access to new ideas, information, and opportunities. On the other hand, too sparse a network can undermine trust and information for long-term alliances. The instructor could lecture on research findings, which show that managers with sparse networks advance more rapidly in their careers.

\section{Strategies For Building Effective Networks}

The instructor might outline a number of steps for building an effective network. First students define their career goals, and assess the resources provided by their current contacts. Then they must assess whether there are major gaps between the resources currently available to them and what they need in order to accomplish their entrepreneurial or professional goals. If they discover gaps, they should consider the cause: are they due to neglect, personal preferences, lack of skill and ability, or other tradeoffs? Finally, students need to formulate strategies that enable them to develop new contacts according to their needs. The instructor might distribute a list of ideas that have proven to strengthen student abilities to construct networks and place evidence in their learning plans. Finally, the instructor could conclude by suggesting that the diversity of my students' network helps make my point that everyone approaches this task differently.

\section{REFERENCES}

1. Aldrich, H. and C. Zimmer (1986). Entrepreneurship through social networks. In D. Sexton \& R. Smiler (eds.), The Art and Science of Entrepreneurship: 3-23. New York: Ballinger.

2. Aldrich, H., S. Birley, P. Dubini, A. Greve, B. Johannisson, P. R. Reese, and T. Sakano (1991). The generic entrepreneur? Insights from a multi-national research project. Paper presented at the Babson Conference on Entrepreneurship.

3. Baker, W. E. (1994). Networking Smart: How to build relationships for personal and organizational success. New York: McGraw-Hill, Inc.

4. Baron, R. A. and G. D. Markham (2003). Beyond social capital: The role of entrepreneur's social competence in their financial success. Journal of Business Venturing, 18, 41-60.

5. Burt, R. S. (1992). Structural Holes: The Social Structure of Competition, Boston: Harvard University Press.

6. Bygrave, W. D. and J. A. Timmons (1992). Venture Capital at the Crossroads, Boston, Harvard Business School: 8.

7. Canfield, J., M. V. Hansen, and L. Hewitt (2000). The Power of Focus, Deerfield Beach, FL. 33442-8190: Health Communications, Inc.

8. Cooper, A. C., T. B. Folta, and C. Woo (1995). Entrepreneurial information search. Journal of Business Venturing, 10(2), 107-120. 
9. Doerr, J. (1997). Fast Company, February-March: 87.

10. Gabbay, S. M. and R. Th. A. J. Leenders (1999). CSC: The structure of advantage and disadvantage. In R. Th. A. J. Leenders \& S. M. Gabbay, (eds.), Corporate Social Capital and Liability: 1-14. Boston: Kluwer Academic Press.

11. Granoveter, M. (1985). Economic action and social structure: the problem of embeddedness, American Journal of Sociology, 91 (3): 481-510.

12. Hansen, E. L. (1995). Entrepreneurial network and new organization growth. Entrepreneurship: Theory \& Practice, 19(4), 7-19.

13. Krackhardt, D. and J. R. Hanson (1993). Informal Networks: The company behind the chart, Harvard Business Review, July-August: 104-111.

14. Lin, N. (1999). Building a network theory of social capital. Connections, 22(1), 28-51.

15. Maister, D. H. (1993). Managing the Professional Service Firm, New York: Free Press.

16. Penning, J. M., K. Lee, and A. van Witteloostuijn (1998). Human capital, social capital, and firm dissolution. Academy of Management, 41:425-440.

17. Pfeffer, J. Managing with power: politics and influence in organizations. Resources, Allies, and the Golden Rule. Boston: Harvard Business School Press, 1992.

18. Portes, A. (1999). Social capital: Its origins and the application in modern sociology. Annual Review of Sociology, 24, 1-24.

19. Smigel, E. O. (1991). Micromotives and Macrobehavior. New York: W.W. Norton and Company.

20. Spence, L. (2004). Forever Friends?: Friendship, Dynamic Relations, and Small Firm Social Responsibility. A working paper presented at the European Group of Organization Studies, $20^{\text {th }}$ Colloquium, Ljubljana, Slovenia, Corporate Social Responsibility and Business Ethics, 1-3 July.

21. Spence, L. J., R. Schmidpeter, and A. Habisch (2003). Assessing Social capital: small and medium sized enterprises in Germany and the U.K. Journal of Business Ethics, 47 (1), 17-29.

22. Tsai, W. and S. Ghoshal (1998). Social capital and value creation: the role of intrafirm networks. Academy of Management, 41: 464-476.

23. Walker, G., B. Kogut, and S. Weijian (1997). Social capital, structural holes and the formation of an industry network. Organization Science 8: 109-125.

\section{TN - EXHIBIT 1 SAMPLE TEACHING PLAN}

1. Introduction (10 minutes)

a. What did you find interesting or surprising in filling out the exercise?

b. What makes for a good entrepreneurial and professional network?

2. Framing the Entrepreneurial Network Exercise (10 minutes)

a. About the instrument

b. Define what is meant by network

3. Interactive Lecture and Conversation (30 minutes)

4. Small Group Discussion (10 minutes)

5. Conclusion (20 minutes)

a. $\quad$ Brief lecture on how to assess your network (see TN-Exhibit 2)

b. Strategies for building competences in effective networks (see TN-Exhibit 3)

c. 17 Ideas for constructing experiential exercise learning opportunities into your learning plan (see TN-Exhibit 4) 


\section{TN - EXHIBIT 2 \\ GUIDELINES FOR DEVELOPING EFFECTIVE NETWORKS}

1. Analyze your development goals and needs.

2. Assess gaps in your current network.
a. What groups are over- or under-represented?
b. Who is missing?
c. Upon who are you over-reliant?
d. What relationships do you need to strengthen?
e. What network circles do you need to add?

3. Formulate strategies in the following areas that will enable you to develop new contacts according to your needs.
a. $\quad$ Launching a new venture
b. $\quad$ Expanding your business
c. $\quad$ Sales and marketing
d. Health and Fitness
e. Communication skills
f. Developing strategic alliances
g. Eliminating debt
h. Raising financial capital

4. Write and practice and "mentor script".

"Hello, Mr. Johnson (not the actual name), my name is Neil. We haven't met yet. And I know you're a busy man, so I'll be brief. I own a small trucking business. Over the years you have done a fantastic job in our industry. I'm sure you had some real challenges when you were first starting out. Well, I'm still in those early stages, trying to figure everything out. Mr. Johnson, I would really appreciate it if you would consider being my mentor. All that would mean is spending ten minutes on the phone with me once a month, so I could ask you a few questions. I'd really appreciate it. Would you be open to that?" 1

5. Pick a time, date and make the call.

It has been shown that the DBN Networking 100 Program works well. Ken Kniesel reported that 95\% of DBM's clients that followed this process landed the job they were looking for within 3 months....regardless of desired salary. Ken also commented that few people had a list of 100 people to contact...but almost everybody have 100 meetings or more within the 4 week period.

a. Have 25 phone or face-to-face meetings each week for 4 weeks. Each meeting must be at least 15 minutes.

b. $\quad$ Send handwritten thank you note out within 24 hours. Handwritten! No Email.

c. Every 3 weeks send an individually addressed email to each person you have met with - give them a quick update of what is new, successes...or give them an offer! Email should be sent between 8PM Friday and Sunday noon. Yes...people do read their email over the weekend. You stand a much better chance of getting your email read and responded to if you send it over the weekend.

\footnotetext{
${ }^{1}$ Adapted from Canfield, J., Hansen M.V. and L. Hewitt (2000). The Power of Focus, Deerfield Beach, FL. 33442-8190, Health

Communications, Inc.
} 


\section{TN- EXHIBIT 3 \\ STRATEGIES FOR DEVELOPING YOUR NETWORK}

1. Be proactive. All encounters are opportunities to develop your network.

2. Broaden your view of from whom you can learn and benefit.

3. Focus on the value you add to the network.
a. Have something to trade
b. Reciprocity may not be immediate
c. Give back to the network not to an individual

4. Take a long-term view.
a. Take incremental steps developing comfort and competence in enhancing your abilities
b. Begin building relationships before you really need them
c. Seek two outcomes:
1) Success in achieving your immediate objective
2) Success importing the relationship such that the next exchange will be more productive

5. Do not become overly dependent on a single mentor and/or your teams.

6. Be realistic. Trust and capability are not established overnight. 


\section{TN - EXHIBIT 4 \\ 17 IDEAS FOR CONSTRUCTING EXPERIENTIAL LEARNING OPPORTUNITIES TO EXPAND YOUR NETWORK INTO YOUR LEARNING PLAN}

1. Attend monthly meetings of a local community or business group of interest to your career with the goal of meeting at least two new people at each meeting.

2. Join a college or university club and attend meetings, participate in functions, and exchange business cards with members and others to whom the club members come into contact with on regular occasions.

3. At each meeting talk with at least two people exchanging business cards and then follow up within 10 to 14 days to develop a working relationship that is mutually beneficial where desirable.

4. Visit with your professor and borrow one of several books he/she has in his/her personal library regarding networking best practices, tools and techniques for developing an entry-level pre-professional network system and write a reflective journal.

5. Obtain and complete the "entrepreneurial networking exercise" model and use the college or university program to track and record the types of people who can contribute to developing your networking system.

6. Plan to have lunch or breakfast at least once every two weeks with someone within the college / university or the external business community but outside your discipline.

7. Attend the college or university Career Day and other academic career planning presentations organized by the school for the expressed purpose of meeting practitioners who may have a mutual interest as you.

8. Join a professional organization or a social/community group in the greater community area to develop contacts with their organization.

9. Utilize the class assignments to find a mentor in the greater community area to meet contacts within his/her organization and write a reflective journal.

10. Maintain a file on individuals that you come in contact with at the school with their personal and professional areas of interest - stay in touch each semester with handwritten notes, email correspondence and periodic visits - being alert for articles or information which might be of interest to the person.

11. Invest in business cards to present to others.

12. Send periodic holiday cards to peers, ex-employers, faculty, and staff as a way to keep contact with these people.

13. Develop good relationships with secretaries and other key informants so that they will be more willing to give your messages to their bosses and write a reflective journal.

14. Actively participate in at least three pre-professional organization meetings on entrepreneurial, managerial or leadership topics.

15. Read Venda Ray-Johnson's book, Effective Networking, to gain a better understanding of successful networking techniques.

16. Volunteer to be a student ambassador or host to guest speakers and at college outreach activities to expand one's network and contacts and write a reflective journal.

17. Read Donna Fisher and Sandy Vilas, Power Networking: 55 Secrets for Personal and Professional Success, Mountain Harbour Publications, 1992. 
NOTES 